\title{
Interactions of Financial Assistance and Financial Reporting Competency: Evidence From Local Government in Papua and West Papua Indonesia
}

\author{
Pilipus Ramandei ${ }^{1,2}$, Abdul Rohman ${ }^{3}$, Dwi Ratmono ${ }^{3} \&$ Imam Ghozali $^{3}$ \\ ${ }^{1}$ Department of Accounting, Diponegoro University, Indonesia \\ ${ }^{2}$ Department of Accounting, University of Ottow Geissler, Papua, Indonesia \\ ${ }^{3}$ Department of Accounting, Faculty of Economics and Business, Diponegoro University, Indonesia \\ Corresponding author: Pilipus Ramandei, Department of Accounting, Faculty of Economics, University of Ottow \\ Geissler, Indonesia.
}

Received: August 6, 2019

Accepted: August 30, 2019

Online Published: October 10, 2019

doi:10.5430/ijfr.v11n1p1

URL: https://doi.org/10.5430/ijfr.v11n1p1

\begin{abstract}
Good local government financial statements are financial statements according to the qualitative characteristics of financial statements, which are relevant, reliable, comparable and understandable. However, the phenomenon shows that there are still weaknesses in financial reporting in several local governments in Indonesia, especially in the provinces of Papua and West Papua based on the findings of the Audit Board of the Republic of Indonesia (IHPS II BPK, 2017). The purpose of this study is to obtain empirical evidence of the role of moderating financial assistance and apparatus competency on the quality of government financial reports. Explanation of the relationship between variables was using an institutional theory perspective. The survey was conducted in 2018 on 42 Local Governments in Papua and West Papua. Methods of processing and analyzing data were using SEM-PLS with WarpPLS 6.0 statistical software. The results of the apparatus competency research have a positive effect on the quality of financial statements. A financial resistance positively strengthens the influence of apparatus competency on the quality of local government financial reports. Thus, efforts to overcome the presentation of quality financial statements require competent apparatus through the existence of financial assistance policies. Limitations of the study are the method of collecting data using a questionnaire and that it is very possible for the bias to occur. Therefore, efforts to achieve better results need to be accompanied by an interview method in order to obtain additional information as a comparison of respondents' answers; 2) the determination coefficient value of R- square is 0.41 or $41 \%$ indicating that there are still 0.59 or $59 \%$ variability in the quality of Local Government Financial Statements (LKPD) which can be explained by other variables outside the research model.
\end{abstract}

Keywords: competence of apparatus, financial assistance, quality of financial reporting

\section{Introduction}

Financial statements are a source of information for stakeholders and are used for decision making. Good quality financial reporting facilitates optimal decision making and allocation of potential resources both in the private sector and the public sector. In the public sector information plays an important role in reducing conflicts of interest inherent in organizations (Yetman \& Yetman, 2004). The quality of government financial reports is a measure of the value of information contained in financial statements and meets the qualitative elements of government financial reports and is used for decision making (Herawati, 2014). Good local government financial statements according to Government Regulation No. 71 of 2010 are financial statements that have relevant, reliable, comparable and understandable characteristics. Relevant, that is information contained in and can influence user decisions by helping evaluate past or present events, and predict the future, and confirm or correct the results of evaluations in the past.

The phenomenon of financial reporting some local governments in Indonesia based on the findings of the Audit Board of the Republic of Indonesia (IHSP II BPK, 2017) of the Local Government Finance Report, namely, apparatus competence in accounting and financial reporting as well as the inadequate internal control system less effective. Findings include weaknesses in accounting controls and reporting, weaknesses in accounting and reporting control systems; recording not/not yet done or inaccurate, the process of preparing a report is not in accordance with the provisions, and weaknesses in the accounting control system and other reporting. Previous research about the quality of 
financial reports and examines the role of some determinant variables such as the competence of human resources, internal control systems, information technology, regulation of internal control over financial reporting quality found different results. According to Altamuro and Beatty (2010), Agus and Ghozali (2019), the company's internal control is influenced by internal control regulations, but needs to be evaluated to be more effective; and changes in regulation of internal control in monitoring and reporting can improve the quality of financial statements. The results of the Doyle et al. (2007) stated that company's ventures will usually face of a lack of resources, complex accounting issues and changes in the business environment, namely through financial reporting controls. Darwanis and Mahyani (2009) present that reliability of financial reporting of local government can be achieved through capacity building of human resources and information technology using. Therefore, the understanding of accounting by the apparatus and the utilization of regional financial accounting information systems can improve the quality of local government financial reports (Yuliani et al. 2010). The role of apparatus competency, good use of information technology and readiness of human resources can improve financial accountability and the accuracy of financial reporting (Winidyaningrum and Rahmawati, 2010; Andriani, 2010; Setiyawati, 2013; Rahayu et al., 2014; Din et al., 2017). According Choirunisah (2008), Napitupulu et al. (2018) quality of local government financial statements are influenced by competence human resources as well as the Government Accounting Standards.

The quality of Local Government Financial Reports in Indonesia, especially in Papua and West Papua Provinces, is still a problem that has not found the right solution. Therefore, efforts to improve the financial management of personnel competence can be pursued with financial assistance policy through advocacy, technical guidance and training of financial reporting is expected to improve the reliability of information in the financial statements of Local Government in Indonesia, with taking samples of Papua and West Papua Provinces.

\section{Literature Review}

\subsection{Institutional Theory}

Institutional theory is used to explain the relationship and influence of the determinants of the quality of financial statements. The formation of an organization is due to institutional environmental pressures that cause institutionalization (DiMaggio \& Powell, 1983). According to DiMaggio and Powell (1983) as a result of institutional pressure, organizations will adopt similar characteristics through the desire to organize themselves in certain ways to be similar to other organizations in the same environment. Organizational adjustments to environmental uncertainty can occur in three ways: coercive isomorphism, mimetic isomorphism and normative isomorphism.

Implementation of institutional theory in the context of local government institutions is deemed necessary to overcome the weaknesses of the financial reporting of local governments in Indonesia. The variety of quality of local government financial reports based on opinion on the examination of financial reports is due to the causes of each local government. Therefore, internal organizations are required to make efforts to improve the presentation of financial reporting so that it can resemble other local government institutions that obtain good financial report quality. This makes apparatus of local government institutions to carry out existing isomorphic mechanisms to achieve the goals of government institutions.

\subsection{Apparatus Competence}

The competency of officials according to BKN Decree No. 46A of 2003 is the ability and characteristics possessed by a State Civil Service in the form of knowledge, skills, and behavioral attitudes needed in carrying out their duties, professionally, effectively and efficiently. Qualifications of State Civil Servants are grouped into three main elements, namely expertise, technical capability and the characteristics of good personnel. Civil servant's expertise includes having experience in accordance with their duties and functions, having deep knowledge in their fields, having broad insight and ethics. Understanding the tasks in the field is the technical ability that must be possessed by civil servants and the characteristics of good employees, among others, must have high discipline, honest, patient, interested, open, objective, good at communicating, always ready and trained. The development of apparatus competencies is carried out through education and training programs. Training according to Smith (2003) is a planned process to change attitudes/behavior, knowledge and skills through learning experiences to achieve effective performance in an activity or a number of activities. Education and training for employees must be provided periodically so that each employee is maintained competency to improve organizational performance through increased productivity, effectiveness and efficiency of the organization (Donalson \& Scannel 1993; Huselid et al., 1997; Rivai 2009).

The development of apparatus competencies through education and training according to Law No. 5 of 2014 states that each state civil apparatus has the right and opportunity to develop competencies. Every government agency must develop a plan for developing the competency of the state civil apparatus in the context of developing the career of the 
state civil apparatus. State civil apparatus competency measurements in career development are technical competencies measured by the level and specialization of education, functional technical training and experience working technically, and managerial competencies measured from the level of education, structural or management training, and leadership experience; and 3) cultural social competencies measured by work experience relating to plural societies in terms of religion, ethnicity and culture so that they have national insight (Suparjo, \& Sunarsih, 2019).

\subsection{Financial Assistance}

According to Kaswan (2012), assistance is a partnership relationship between coaches and employees that focuses on continuous learning, growth, change, which brings results in the development of the fulfillment of one's internal resource needs. Assistance directs directly or indirectly the energy and desires of employees to increase motivation, achieve goals, and maximize potential (Kaswan 2012). This statement is supported by the results of the study of Halen and Astuti (2013), the level of understanding of the apparatus about duties and responsibilities, training and apparatus assistance in financial management fostering has an effect on organizational performance in financial management. Financial assistance to financial management, especially the preparation of local government financial reports in Indonesia, is a moderating variable to improve the competency of officials in the financial statements. Financial assistance is analyzed based on the leadership policy in an effort to increase the internal resources of the apparatus and its benefits in guiding the management and presentation of Local Government Financial Reports (LKPD).

\subsection{Hypothesis Development}

\subsubsection{Apparatus Competence and Quality of Financial Reporting}

Normative isomorphism in institutional theory is related to professionalism. The norm or something that is right for the organization originates from formal education and the socialization of formal knowledge in certain fields that support and disseminate the normative beliefs of institutions to make adjustments to resemble other organizations (DiMaggio \& Powell, 1983). Organizational adjustments in institutional theory review include personnel adjustments, namely organizations need to make adjustments to institutional rules through the use of specific personnel both internally and externally.

Harmon and Mayer (1986) discusses the need for human resource capacity to sustain democratic and politically accountable governance management processes that complement the technical gains that must be possessed by the bearers of public responsibility mandates. The implementation of the mandate of responsibility within the scope of the regional government is manifested in the accountability of the community mandate, through financial management accountability reports, including the submission of regional government financial reports. Information presented in the financial statements of regional governments must meet the quality elements of financial statements and provide relevant information so that they can be used in decision making. Thus, human resources, systems, organizations, and external factors are critical factors in the quality of accounting information (Xu et al., 2003). Furthermore, the research results of Nuryanto and Afiah (2013) explain that apparatus competencies can influence the quality of financial statements. Therefore, ownership of human resources with adequate competencies tends to increase the quality of local government financial reports (Darwanis \& Mahyani, 2009; Andriani 2010; Indriasih \& Koeswayo, 2014; Agung \& Winarningsih, 2016; Rahayu et al., 2014; Fakhimuddin, 2018).). Thus, the apparatus with sufficient competence in the local government in Indonesia can improve the quality of local government financial reports. This is reasonable according to Choi et al. (2013) stating that the way to overcome the root of the problem in reporting is through investing in human resources in internal control and accounting in order to improve the quality of reporting. Thus, the research hypothesis is proposed:

H1: Apparatus competency has a positive effect on the quality of Local Government Financial Reports.

2.4.2 The Role of Financial Assistance as Moderating the Effect of Apparatus Competence on the Quality of Local Government Financial Reports

The existence of organizations occurs at a broad organizational scope with the view that each organization influences the other forms of organization through the process of adoption or institutionalization (DiMaggio \& Powell, 1983). Mimetic isomorphism describes the process of adjustment when an organization mimics other organizations, usually due to uncertainty.

The achievement of the opinion of the unqualified local government financial statements indicates the better quality of financial statements. On the contrary, this condition is different from the acquisition of opinions in some local governments, which tend to show the quality of financial reports that are not optimal. The tendency of the acquisition of opinions on the financial statements may be caused by the human resources, existing systems and external factors. This is the reason and obligation of local governments to carry out the evaluation and coaching process of financial 
assistance through other organizations that have capability in the process of good management so that they can give good results in the local government financial reporting process.

Assistance directs directly or indirectly the energy and desires of employees to increase motivation, achieve goals, and maximize potential (Kaswan, 2012). The intensity of the implementation of assistance in the provision of understanding and assistance as well as guidance on the preparation and preparation of financial statements can have an impact on organizational readiness and the resolution of obstacles in the process of preparing financial statements. On the other hand, technical guidance and assistance in financial management, especially administration and reporting, need to be carried out at the Level of Regional Work Unit (SKPD) so that it has an impact on the comprehensive financial reporting of regional governments (Kahar et al., 2016; Kahar et al., 2019).

Halen and Astuti (2013) stating the level of understanding of the apparatus on duties and responsibilities, training and apparatus assistance in financial management fostering is very influential on organizational performance in financial management. Therefore, financial assistance policies through mentoring and technical guidance with supervisory institutions, consultants and professional staff, and academics in order to increase the capacity and competence of the apparatus are expected to have an internal impact on the financial reporting process. Thus, the research hypothesis is proposed, as follows:

H2: Financial assistance moderates the relationship between apparatus competency and the quality of Local Government financial statements.

\section{Research Method}

Respondents of this study included 42 regional governments in the provinces of Papua and West Papua, Indonesia. The number of local government was grouped into 2 provincial governments and 40 district government. Survey was carried out for all local government in the province of Papua and West Papua. The unit of analysis in this study was conducted with an interaction testing between financial assistance, personnel competence, and the quality of the financial statements. The analysis is more focused on the competency of the apparatus and financial assistance support in improving the competency of the apparatus in the presentation of financial statements of local governments in Indonesia. The data collection 2018 research conducted by using research questionnaire distributed to 42 local government through the Regional Finance Management Task Force (SKPKD) in Papua and West Papua as resource management.

\subsection{Variable Measurement}

The research variables consisted of exogenous variable of apparatus competency and endogenous variable of financial report quality as well as moderating variable of financial assistance. Measurement of research variables was presented in Table 1.

Table 1. Measurement of variables

\begin{tabular}{ll}
\hline Variable & Measurement \\
\hline Apparatus Competence (AC) & $\begin{array}{l}\text { The instrument consisted of 11 statement items that were adapted and } \\
\text { developed based on apparatus competency indicators (Nuryanto \& Afiah } \\
\text { 2013). The measure of the competency level of the apparatus is based on } \\
\text { the respondent's response to a series of items using a five-point scale. }\end{array}$ \\
\hline $\begin{array}{l}\text { Quality of } \\
\text { Statements (QFS) }\end{array}$ & $\begin{array}{l}\text { The instrument consists of } 13 \text { statement items adapted and developed } \\
\text { based on the operational definition of financial report quality (Jonas \& } \\
\text { Blanchet 2000). The measure of the quality of financial statements is } \\
\text { based on the responses of subjects to a series of items using a five-point } \\
\text { scale. }\end{array}$ \\
\hline Financial Assistance (FA) & $\begin{array}{l}\text { The instrument consists of five statement items developed and adapted } \\
\text { from (Taruru et al. 2015). The measure of the application of financial } \\
\text { assistance is based on the responses of subjects to a series of items using a } \\
\text { five-point scale. }\end{array}$ \\
\hline
\end{tabular}




\subsection{Data Analysis}

Technical analysis is path analysis using Structural Equation Modeling-SEM-PLS with WarpPLS 6.0 Software. The results of descriptive statistical analysis include the range of minimum and maximum values theoretically and accurately, the mean, and the standard deviation for each variable are listed in Table 2.

Table 2. Descriptive statistics of research variables

\begin{tabular}{llllll}
\hline Variable & $\begin{array}{l}\text { Theoretical } \\
\text { Range }\end{array}$ & $\begin{array}{l}\text { Theoretical } \\
\text { Mean }\end{array}$ & $\begin{array}{l}\text { Actual } \\
\text { Range }\end{array}$ & $\begin{array}{l}\text { Empirical } \\
\text { Average }\end{array}$ & $\begin{array}{l}\text { Standard } \\
\text { Deviation }\end{array}$ \\
\hline Apparatus Competence (AC) & $1-5$ & 3 & $3-5$ & 3.75 & $0.45-0.59$ \\
\hline Financial Assistance (FA) & $1-5$ & 3 & $4-5$ & 4.86 & $0.30-0.43$ \\
\hline Quality of Financial Statements (QFS) & $1-5$ & 3 & $4-5$ & 4.54 & $0.43-0.51$ \\
\hline
\end{tabular}

Source: SPSS 21 output.

Table 2 shows the variable of apparatus competency measured by 11 statements (AC1-AC11). On the other hand, the empirical descriptive statistics showed respondents' answers to the apparatus competency variable. The average respondent's answer to the financial report quality variable is 3.75 from a score range of 1-5 so that the respondent's answers are categorized as moderate. These results illustrate human resources or apparatus owned by local governments in Papua and West Papua with sufficient levels of competence. Variable of financial assistance is measured by 5 statements (FA1-FA5). Table 2 show empirical results of descriptive statistics on respondents' answers to statements of financial assistance variables. The average respondent's answer to financial assistance variables is 4.86 from a range of scores 1-5 so that the respondent's answers are high. This result illustrates that the implementation of financial assistance to the process of preparing financial statements of local governments in Papua and West Papua Provinces is very good. Descriptive statistics on financial report quality variables (QFS) measured by 13 statements (QFS1-QFS 13). Table 2 show empirical results of descriptive statistics on respondents' answers to variable statements of financial statement quality. The average respondent's answer to the financial report quality variable is 4.54 from a score range of 1-5 so that the respondent's answers tend to be high. This result illustrates the relatively high financial reporting process in presenting the financial statements of local governments in Papua and West Papua provinces.

\section{Research Findings and Discussion}

\subsection{Test Results for Measurement Models, Structural Models and Hypothesis Tests}

Structural Equation Modeling analysis includes 2 (two) stages of Hair et al. (2013) namely measurement model and structural model. The following are the test results for each stage.

\subsubsection{Evaluation of Measurement Model (Outer Model)}

Evaluation of measurement models is used to assess the reliability and validity of each research construct. There are 2 criteria that must be met in reliability testing: 1) composite reliability greater than 0.70; and 2) Cronbach's alpha is greater than 0.70 . The results of reliability testing are presented in Table 3 .

Table 3. Reliability test results

\begin{tabular}{lllll}
\hline & $\begin{array}{l}\text { Apparatus } \\
\text { Competence (AC) }\end{array}$ & $\begin{array}{l}\text { Quality of Financial } \\
\text { Statements (QFS) }\end{array}$ & $\begin{array}{l}\text { Financial } \\
\text { Assistance (FA) }\end{array}$ & $\begin{array}{l}\text { Interaction } \\
\text { AC*FA }\end{array}$ \\
\hline Composite reliability & 0.947 & 0.943 & 0.932 & 0.984 \\
\hline Cronbach's alpha & 0.936 & 0.934 & 0.907 & 0.983 \\
\hline
\end{tabular}

Source: Output WarpPLS 6.0.

Table 3 shows the composite reliability values for each construct greater than $>0.70$ and Cronbach's alpha above $>0.70$. This indicates that the instrument used to measure variables has good reliability. Reliability reflects that the instrument 
used to measure the variables of this study consistently has the same results every time a measurement is made. Furthermore, the results of the validity test are shown in Table 4.

Table 4. Discriminant validity

\begin{tabular}{lllll}
\hline & AC & QFS & FA & AC*FA \\
\hline Apparatus Competence (AC) & $\mathbf{0 . 8 1 5}$ & 0.540 & 0.012 & -0.042 \\
\hline Quality of Financial Statements (QFS) & 0.540 & $\mathbf{0 . 7 4 8}$ & 0.431 & 0.065 \\
\hline Financial Assistance (FA) & 0.012 & 0.431 & $\mathbf{0 . 8 5 7}$ & 0.111 \\
\hline AC*FA Interaction & -0.042 & 0.065 & 0.111 & $\mathbf{0 . 7 4 7}$ \\
\hline
\end{tabular}

Source: Output WarpPLS 6.0. The square roots of variance extracted (AVEs) are shown on diagonals.

Rated cross loading in Table 4 shows that the criteria for discriminant validity are fulfilled. Indications of fulfilling discriminant validity can be seen from the results of the AVE root values that are greater than other construct correlations. AVE root results in the diagonal column show all variables have higher AVE roots than other construct correlations ( $\mathrm{AC}=0.815$; $\mathrm{QFS} 0.748 ; \mathrm{FA}=0.857$ and $\mathrm{AC} * \mathrm{FA}=0.747$ ). The value of cross loading and root $\mathrm{AVE}$ shows that the discriminant validity of the instrument in this study is believed to be fulfilled.

\subsubsection{Evaluation of Structural Models (Inner Model)}

Structural model testing is carried out after the fulfillment of model suitability criteria according to the theory with empirical data. Table 5 displays the results of the fit model indicators, namely Average Path Coefficient (APC), Adjusted Average R-squared (AARS), and Average Variance Inflation Factor (AVIF). The model fit rate has been fulfilled, namely the p value for APC and AARS $<0.05$ and AVIF $<5$ (Kock, 2012) in Table 5.

Table 5. Model fit test results

\begin{tabular}{llll}
\hline Parameter & Value & p value & Conclusion \\
\hline Average Path Coefisient (APC) & 0.379 & $\rho=0.002 *$ & $\mathrm{P}=<0.05$ \\
\hline Average R-square (ARS) & 0.409 & $\rho<0.001 *$ & $\mathrm{P}=<0.05$ \\
\hline Average Adjusted R-squared (AARS) & 0.379 & $\rho<0.001 *$ & $\mathrm{P}=<0.05$ \\
\hline Average Variance Inflation Factor (AVIF) & 1.220 & & $\mathrm{AVIF}<0.05$ \\
\hline Average Full Collinearity VIF (AFVIF) & 1.453 & & $\mathrm{AFVIF}<0.05$
\end{tabular}

Source: Output WarpPLS 6.0. Note: ${ }^{*}=\alpha<0.05$

Based on the results of Table 5, the fit indices and $\mathrm{P}$ value models have been fulfilled, so that a structural model analysis can be carried out. The test results structural models presented in Figure 2.

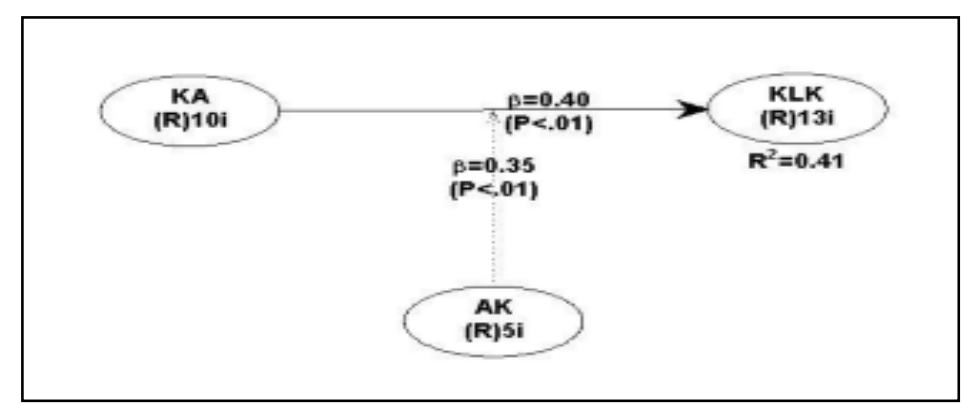

Figure 1. Structural model test results

*Note: $\mathrm{KA}=$ apparatus competency/AC; KLK= quality of financial statements $(\mathrm{QFS}) ; \mathrm{AK}=$ financial assistance/FA 


\subsubsection{Hypothesis Test Results}

Based on the estimation results of the structural model, the value of the hypothesis testing results is shown in Table 5.

Table 5. Hypothesis test results

\begin{tabular}{lllll}
\hline Path & $\boldsymbol{\beta}$ & p value & Hypothesis & Results \\
\hline $\mathrm{AC} \rightarrow$ QFS & 0.40 & $<0.001^{*}$ & $(+)$ & accepted \\
\hline Interaction AC*FA $\rightarrow$ QFS & 0.35 & $<0.001^{*}$ & $(+)$ & accepted \\
\hline
\end{tabular}

Source: Output WarpPLS 6.0. Note: ${ }^{*}=\alpha<0.05$;

The testing results of the first hypothesis show the significant effect of apparatus competency on the quality of financial statements with $p$-value of $<0.001$ and the path coefficient value of 0.40 . Thus, the first hypothesis stating that apparatus competency has a positive effect on the quality of financial statements was supported by empirical evidence. On the other hand, the statistical testing of hypothesis 2 shows a positive and significant interaction of financial assistance and apparatus competence with significant value of $\mathrm{p}<0.001$ and path coefficient value of 0.35 . Thus, hypothesis 2 is proven by empirical evidence that the interaction of financial assistance and apparatus competency influences the quality of financial statements.

Based on the results of the hypothesis testing on the full model, it was revealed that the competency of the apparatus influences the quality of Government Financial Reports. This can be interpreted that in theory the apparatus with adequate competence related to knowledge, expertise and good behavior in the implementation of duties and responsibilities in the process of managing regional finance will have an effect on the financial reporting process. Although the conditions of apparatus competence in the area he Government of Papua and West Papua which inadequate competence of apparatus can affect the quality of financial reporting. Therefore, the presentation of quality financial statements requires an increase in the apparatus' competency. The results of testing the moderating variable show the positive and significant effect of mediating variable of financial assistance in strengthening the influence of apparatus competence on the quality of financial reporting. The competency of the apparatus in the regional government will be likely to increase with the existence of financial assistance in the financial reporting process. This tends to improve the quality of local government financial reports especially in Papua and West Papua Provinces, and Indonesia in general.

\subsubsection{Moderating Effect Testing Results}

The results of testing the moderation effect in Figure 1 show the moderating variable by using the Pure Moderator. The testing of the moderation model is done by examining the effect of moderating variable influence of financial assistance on the relationship between the apparatus competency and the quality of local government financial reports. The testing of the moderation hypothesis is done by moderated regression analysis (MRA) by considering the interaction, coefficient value and the hypothesis acceptance with significant value (Kock, 2011).

The test results are moderated by pure moderator referring to the AVIF value must be the focus because in SEM-PLS interactions between variables with Moderated Regression Analysis allow multicollinearity to occur. The research findings prove that based on the output model fit and quality indices, the research model is fit. The path coefficients and the $\rho$-value of moderating variable of financial assistance on the relationship between apparatus competence and the quality of financial statements, namely the path $\mathrm{AC} * \mathrm{FA} \rightarrow$ QFS shows the coefficient value of 0.35 and significant at the value $\rho=<0.001$. These results are interpreted that the interaction of financial assistance with the competence of the apparatus can improve the competency of the apparatus which includes knowledge, expertise, behavior, and their influence on the quality of financial reporting in local governments in Papua and West Papua.

\section{Discussion}

\subsection{Apparatus Competence and Quality of Financial Statements}

The findings reveal the existence of the apparatus in the regional government in Papua and West Papua with a level of knowledge, expertise and behavior that is relatively adequate and can guarantee the presentation of quality financial statements. However, efforts to increase the competency of officials in the process of reporting and presenting financial statements of regional governments in Papua and West Papua through training and technical guidance to address the problem of lack of human resources in the field of financial management so that it influences the financial reporting of 
local governments. Increasing the competency of the apparatus can be achieved through financial assistance policies or assistance in the financial reporting process as well as reviewing or evaluating the preparation of financial statements so as to improve the competency of the apparatus and influence the quality of financial statements.

Empirical evidence supports the perspective of institutional theory that the local government as an institution will be able to maintain its existence in the presentation of financial statements properly due to the existence of 'coercion' of regulation of financial management with the adjustment through policies of financial assistance that the financial statements of local governments in Papua and West Papua can achieving quality financial statements. Therefore, in order to produce good quality financial reports, local governments in Papua and West Papua need to adjust (mimetic isomorphism) the process of preparing financial reporting with other institutions or parties through enhancement (normative isomorphism) of apparatus competencies in terms of knowledge, expertise, behavior in the financial reporting process. Fulfillment of apparatus competency includes knowledge of the rules in financial reporting, as well as understanding of duties and responsibilities, technical expertise and the behavior of good officers can support efforts to achieve the quality of Local Government Financial Reports in Papua and West Papua, Indonesia.

This finding supports the results of Xu et al. (2003) demonstrating that critical factors determining the quality of accounting information are such as human resources, systems, organizations and external factors. The meaning of the results of this study is that the determinants of information quality are not only Human Resources (HR), but also organizational factors and external factors. Thus, the achievement of the quality of local government financial reports requires government personnel in the local government financial reporting process. However, the condition of local governments with the capacity of the human resources is not adequate, necessary adjustment to for sustainability human resources through improving the knowledge, skills and behavior in the financial reporting process in order to assess the effectiveness of financial reporting and compliance with accounting systems.

\subsection{Financial Assistance Interaction and Apparatus Competence on the Quality of Financial Statements}

The test results prove that the influence of apparatus competency on financial report quality, moderated by financial assistance with coefficient of 0.35 and significant at $\rho=<0.001$. These results indicate a significant ( $\rho$-value) effect, and have a positive coefficient path direction. Thus, it is concluded that financial assistance in the financial reporting process can improve the competency of the apparatus towards the quality of the local government financial report in Indonesia.

This research supports the perspective of institutional theory that explains how organizations try to adjust to external pressure to maintain their existence. Although human resources the financial reporting processes of local governments in Provincial Papua and West Papua, Indonesia, are relatively inadequate but the implementation of assistance to finance will be more likely to increase the competence of the apparatus that includes knowledge, skills and behavior in the process of preparing the financial statements of local government. On the other hand, this empirical evidence confirms the institutional theory of elements normative isomorphism, which can be associated with professionalization and capture normative pressures that arise in certain fields. Furthermore, the norm or something that is right for the organization comes from formal education and socialization of formal knowledge of certain fields that support and spread normative beliefs. Mimetic isomorphism describes the process of adjustment when an organization mimics other organizations, usually due to uncertainty (DiMaggio \& Powell, 1983).

The coefficient of interaction between financial assistance and apparatus competency has a positive direction, meaning that the higher the value of financial assistance, the higher the competency of the apparatus towards the quality of financial statements. The role of financial assistance moderation on the positive influence of apparatus competency on the quality of financial statements is shown in Figure 2.
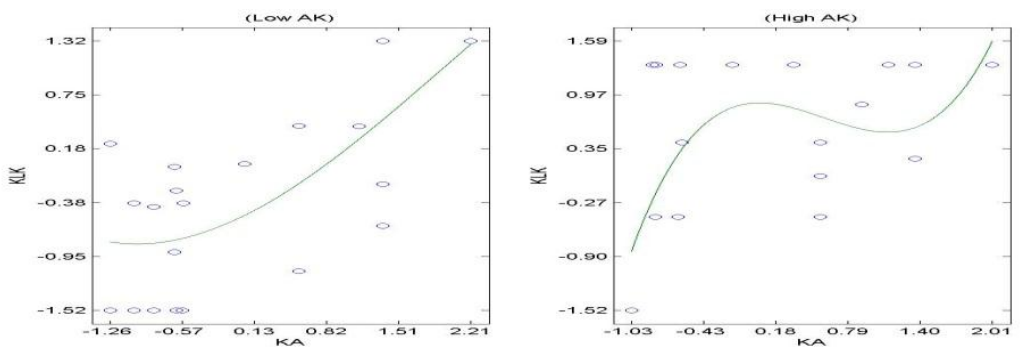

Figure 2. Low financial assistance and high financial assistance 
Figure 2 shows the pattern of influence of apparatus competency on the quality of financial statements under conditions of low financial assistance and high conditions of financial assistance. In conditions of low financial assistance, the influence of apparatus competency on the quality of financial statements is weaker compared to the conditions of high financial assistance. High apparatus competencies will improve the quality of financial statements. Thus, the existence of high financial assistance will increase the higher or more competent apparatus and there is a tendency for the better financial reporting process to achieve the quality of Local Government Financial Reports (LKPD).

This finding directly implied to improve the competency of the apparatus in the process of good local government financial reports, the implementation of guidance and assistance for the apparatus in the financial reporting process in order to improve the quality of financial reports in Indonesia, especially in Papua and West Papua. The results of this study support the statement of Kaswan (2012) stating that assistance directs, directly or indirectly, energy and desire of employees to increase motivation, goals, and maximize the potential. A financial resistance carried out based on the leadership policy in implementing guidance on financial management and reporting processes in the area of regional financial accounting can improve apparatus competency in financial reporting knowledge and expertise. The intensity of the implementation of assistance in providing understanding and assistance as well as guidance on the preparation and preparation of financial statements can affect the readiness of the organization and the resolution of obstacles in the process of preparing financial statements. These results support previous research related to the impact of implementing assistance to employee and organizational performance (Halen \& Astuti 2013; Taruru et al. 2015). The more intensive implementation of financial assistance through the presence of technical guidance and training in financial management can improve the competence of the apparatus in an effort to present quality local government financial reports.

Overall, this study empirically proves that there is a positive relationship between apparatus competence and the quality of local government financial reports. These results support previous studies from McLeod \& Harun (2014) that bureaucratic reform in Indonesia is severely hampered by a lack of staff competence with inadequate accounting skills.

The main contribution of this paper is to highlight that in connection with the practice of fiscal decentralization and bureaucratic reform in Indonesia, decentralization is carried out in a hurry, making local governments less prepared in preparing financial systems and standard accounting styles, and lacking competent staff, in turn this tends not to be able to improve the presentation of quality financial reporting. Another controversy from this study is to make it clear that political decentralization does not go hand in hand with the equitable quality of local government staff. By highlighting the Papuan government, which is one of the least developed regions in Indonesia, this study makes it clear that this gap exists. This is in line with Lewis and Hendrawan (2019), who highlighted the relationship of patterns of power in the region to the quality of public services, in relation to the implementation of a decentralized system, which gave rise to corruption and waste of regional budgets.

This also relates to the second test of this study that financial assistance, from the central government through the assistance of competent staff in preparing local government financial reports. The test results prove that financial assistance is able to empirically moderate and actually bridge the influence of apparatus competence on the quality of financial statements. The empirical evidence found from this study supports the arguments of Harun et al. (2019) that public sector reforms in Indonesia have not succeeded in improving governance goals and preventing corruption. This can at least emerge from the low quality of financial statements which is more likely to be associated with an increase in corruption cases (Furqan \& Din, 2019; Graycar, 2015).

\section{Conclusions, Implications and Limitations of Research}

\subsection{Conclusion}

Based on the results of research and discussion, it was concluded that the interaction of financial assistance and personnel competence affect the Local Government Financial Reports in Papua and West Papua. Therefore, efforts to address the human resource competencies are inadequate related to knowledge, skills and behavior in the financial reporting process of local government. It is required to increase the competence of government officials through a

policy of financial assistance. Assistance or mentoring and guidance at the stage of the financial report preparation process can improve competency officers of the presentation Local Government Financial Reports in Papua and West Papua, Indonesia, corresponding element of the quality of financial statements. 


\subsection{Theoretical Implications}

Perspective institutional theory with efforts to achieve the quality of financial reporting through the assistance of financial namely how government institutions local government in Papua and West Papua to make adjustments as a result of coercive efforts to obtain the opinion of unqualified on the financial statement audit, the policy of assistance to finance needs to be executed in order to empower the apparatus through increasing knowledge, expertise and behavior through (mimetic) other institutions. This effort is expected to produce a professional (normative) apparatus in the field of financial management and reporting and has the capability and competence in the presentation of quality local government financial reports.

\subsection{Practical Implications}

The results of this research contribute to policy implications for local governments in Papua and West Papua, Indonesia, especially the local government that is the result of regional autonomy in regency/city. This is implied that, first, competence officials in local government include knowledge, skills and behavior is an important factor in financial management and reporting. Therefore, the recruitment and placement of human resources must be selective and based on specific needs and competencies to have an effect on local government financial reporting. Secondly, The quality of local government financial reports in Indonesia, especially Papua and West Papua, is more likely to improve, if supported by the availability of apparatus with adequate competence, and third, measures to human resource development in order to improve the quality of financial reporting by local government through assistance to finance that process guidance of the technical, financial, training and assistance in the preparation of financial statements, is expected to be transfer of knowledge and expertise of financial reporting from external professional parties.

\subsection{Research Limitations}

The limitations of this study can be a reference for further research that the data collection method uses a research instrument in the form of a questionnaire and is very possible for the occurrence of bias. Therefore, efforts to achieve better results need to be accompanied by an interview method in order to obtain additional information as a comparison of respondents' answers, and value of coefficient determination R-Square of 0.41 or $41 \%$ indicated that they contained 0.59 or $59 \%$ variability in the quality of Local Government Financial Reports (LKPD) can be explained by other variables outside the research model. This opens the opportunity for the researchers to consider the role of other variables in improving the quality of local government financial reports.

Beyond that this study is to examine specifically the quality of financial reports on the government of Papua, which is limited to only having 42 administrative districts, there may be problem in the design of the study. This study is to clarify the need for financial assistance to improve governance in Indonesia, which, although with a limited sample, generalizability through the coefficient of determination estimates at least $40 \%$ of the influence of the quality of financial statements is influenced by the independent variable of apparatus competence. However, The sample size is small for adequate statistical treatment. A small sample size may affect the reliability of a survey's results because it leads to a higher variability, which may lead to bias with the most common case of bias being a result of non-response. Hence, further studies need to add more sample to come up with a conclusive finding.

\section{References}

Agung, M., \& Winarningsih, S. (2016). Effect of Auditor and Internal Control Competence Apparatus for Local Government Quality of Financial Reporting. European Journal of Accounting, Auditing and Finance Research, 4(7), 113-127.

Agus, A., \& Ghozali, I. (2019). Mediating Effect of Audit Quality in Relationship Between Auditor Ethics and Litigation: An Empirical Study. International Journal of Economics \& Business Administration (IJEBA), 7(2), 91-100.

Altamuro, J., \& Beatty, A. (2010). How does internal control regulation affect financial reporting?. Journal of Accounting and Economics, 49(1-2), 58-74. https://doi.org/10.1016/j.jacceco.2009.07.002

Andriani, W. (2010). Pengaruh Kapasitas Sumber Daya Manusia dan Pemanfaatan Teknologi Informasi Terhadap Keterandalan dan Ketepatwaktuan Laporan Keuangan Pemerintah Daerah (Studi pada Pemerintah Daerah Kab. Pesisir Selatan ). Jurnal Akuntansi \& Manajemen, 5(1), 69-80.

Choi, J. H., Lee, J., \& Sonu, C. H. (2013). Determinants of human resource investment in internal controls. China Journal of Accounting Research, 6(3), 167-185. https://doi.org/10.1016/j.cjar.2013.06.003

Choirunisah, F. (2008). Faktor-faktor yang mempengaruhi kualitas informasi laporan keuangan yang dihasilkan sistem akuntansi instansi. Jurnal Universitas Gajahmada. 
Darwanis, D., \& Mahyani, D. D. (2009). Pengaruh Kapasitas Sumber Daya Manusia, Pemanfaatan Tehnologi Informasi Dan Pengendalian Intern Akuntansi Terhadap Keterandalan Pelaporan Keuangan Pemerintah Daerah. Jurnal Telaah dan Riset Akuntansi, 2(2), 133-151.

DiMaggio, P. J., \& Powell, W. W. (1983). The iron cage revisited: Institutional isomorphism and collective rationality in organizational fields. American Sociological Review, 147-160. https://doi.org/10.2307/2095101

Din, M., Munawarah, Ghozali, I., \& Achmad, T. (2017). The follow up of auditing results, accountability of financial reporting and mediating effect of financial loss rate: An empirical study in Indonesian local governments. European Research Studies Journal, 20(4), 443-459

Donalson, L., \& Scannel, E. E. (1993). Pengembangan Sumber Daya Manusia. Jakarta: Gaya Media Pratama.

Doyle, J., Ge, W., \& McVay, S. (2007). Determinants of weaknesses in internal control over financial reporting. Journal of Accounting and Economics, 44(1-2), 193-223. https://doi.org/10.2307/2095101

Fakhimuddin, M. (2018). Reconsidering Accounting Information Systems: Effective Formulations for Company's Internal Control. Arthatama Journal of Business Management and Accounting, 2(1).

Furqan, A. C., \& Din, M. (2019). Social perception on corruption and its influence on public legitimacy and open government. Revista Espacios, 40(13).

Graycar, A. (2015). Corruption: Classification and analysis. Policy and Society, 34(2), 87-96. https://doi.org/10.1016/j.polsoc.2015.04.001

Hair, J. F., Black, W. C., Babin, B. J., \& Anderson, R. E. (2013). Multivariate data analysis: Pearson new international edition. Pearson Higher Ed.

Halen, H., \& Astuti, D. D. (2013). Pengaruh Tingkat Pemahaman, Pelatihan dan Pendampingan Aparatur Pemerintah Daerah terhadap Penerapan Accrual Basis dalam Pengelolaan Keuangan Daerah di Kabupaten Jember (Studi Kasus pada Dinas Pemerintahan Kabupaten Jember). Relasi: Jurnal Ekonomi, 18, 98-119.

Harmon, M. M., \& Mayer, R. T. (1986). Organization Theory for Public Administration. Little, Brown \& Company.

Harun, H., Mir, M., Carter, D., \& An, Y. (2019). Examining the unintended outcomes of NPM reforms in Indonesia. Public Money \& Management, 39(2), 86-94. https://doi.org/10.1080/09540962.2019.1580892

Herawati, T. (2014). Pengaruh Sistem Pengendalian Intern Terhadap Kualitas Laporan Keuangan (Survei Pada Organisasi Perangkat Daerah Pemda Cianjur). STAR-Study \& Accounting Research, 11(1), 1-14.

Huselid, M. A., Jackson, S. E., \& Schuler, R. S. (1997). Technical and strategic human resources management effectiveness as determinants of firm performance. Academy of Management Journal, 40(1), 171-188. https://doi.org/10.5465/257025

Indriasih, D., \& Koeswayo, P. S. (2014). The effect of government apparatus competence and the effectiveness of government internal control toward the quality of financial reporting in local goverment. Research Journal of Finance and Accounting, 5(20), 38-47.

Jonas, G. J., \& Blanchet, J. (2000). Assessing quality of financial reporting. Accounting Horizons, 14(3), $353-363$. https://doi.org/10.2308/acch.2000.14.3.353

Kahar, S. H., Ikbal, M., Jabid, A. W., \& Purbaya, A. (2019). Ethical Optimism, Participative Budgeting, and Managerial Performance in Regional Government Work Unit in Indonesia: A Contingency Theory Approach. Calitatea, 20(171), 70-75.

Kahar, S. H., Rohman, A., \& Chariri, A. (2016). Participative budgeting, budgetary slack and job satisfaction in the public sector. Journal of Applied Business Research (JABR), 32(6), 1663-1674. https://doi.org/10.19030/jabr.v32i6.9814

Kaswan. (2012). Manajemen Sumber Daya Manusia untuk Keunggulan Bersaing Organisasi. Yogyakarta: Graha Ilmu.

Kock, N. (2011). Using WarpPLS in e-collaboration studies: Mediating effects, control and second order variables, and algorithm choices. International Journal of e-Collaboration (IJeC), 7(3), 1-13. https://doi.org/10.4018/jec.2011070101 
Lewis, B. D., \& Hendrawan, A. (2019). The impact of majority coalitions on local government spending, service delivery, and corruption in Indonesia. European Journal of Political Economy, 58, 178-191. https://doi.org/10.1016/j.ejpoleco.2018.11.002

McLeod, R. H., \& Harun, H. (2014). Public sector accounting reform at local government level in Indonesia. Financial Accountability \& Management, 30(2), 238-258. https://doi.org/10.1111/faam.12035

Napitupulu, S., Haryono, T., Laksmi Riani, A., Sawitri, H. S. R., \& Harsono, M. (2017). The impact of career development on employee performance: an empirical study of the public sector in Indonesia. International Review of Public Administration, 22(3), 276-299. https://doi.org/10.1080/12294659.2017.1368003

Nuryanto, M., \& Afiah, N. N. (2013). The Impact of Apparatus Competence, Information Technology Utilization and Internal Control on Financial Statement Quality (Study on Local Government of Jakarta Province-Indonesia). World Review of Business Research, 3(4), 157-171.

Rahayu, S. (2014). Implementasi Peraturan Pemerintah Nomor 71 Tahun 2010 Tentang Standar Akuntansi Pemerintahan Berbasis Akrual Dan Standar Akuntansi Pemerintahan Berbasis Kas Menuju Akrual Di Jombang. Thesis, UPN Veteran East Java.

Rivai, V. (2009). Manajemen sumber daya manusia untuk perusahaan: Dari teori ke praktik. Rajawali Pers.

Setiyawati, H. (2013). The effect of Internal Accountants' Competence, Managers' Commitment to Organizations and the Implementation of the Internal Control System on the Quality of Financial Reporting. International Journal of Business and Management Invention, 2(11), 19-27.

Smith, P. J. (2003). Workplace learning and flexible delivery. Review of Educational Research, 73(1), 53-88. https://doi.org/10.3102/00346543073001053

Suparjo, \& Sunarsih, E. S. (2019). Creativity and Transformational Leadership on Public Sector Employee Performance. Academy of Entrepreneurship Journal, 25(3).

Taruru, I., Keriko, J. M., Ombui, K., Karanja, K., \& Tirimba, O. I. (2015). Effects of coaching programmes on employee performance in business process outsourcing subsector of Nairobi city county, Kenya. International Journal of Scientific and Research Publications, 5(3), 1-30.

Winidyaningrum, C., \& Rahmawati. (2010). Pengaruh sumber daya manusia dan pemanfaatan teknologi informasi terhadap keterandalan dan ketepatwaktuan pelaporan keuangan pemerintah daerah dengan variabel intervening pengendalian intern akuntansi (Studi Empiris Di Pemda Subosukawonosraten). Simposium Nasional Akuntansi XIII Purwokerto.

Xu, H., Horn Nord, J., Daryl Nord, G., \& Lin, B. (2003). Key issues of accounting information quality management: Australian case studies. Industrial Management \& Data Systems, 103(7), 461-470. https://doi.org/10.1108/02635570310489160

Yetman, M. H., \& Yetman, R. J. (2004, July). The effects of governance on the financial reporting quality of nonprofit organizations. Conference on not-for-profit firms, Federal Reserve Bank (Vol. 238). New York.

Yuliani, S., Nadirsyah, \& Bakar, U. (2010). Pengaruh pemahaman Akuntansi, Pemanfaatan Sistem Informasi Akuntansi Keuangan Daerah dan Peran Internal Audit terhadap Kualitas Laporan Keuangan Pemerintah Daerah (Studi pada Pemerintah Kota Banda Aceh). Jurnal Telaah \& Riset Akuntansi, 3(2), 206-220. 